\title{
molecules
}

ISSN 1420-3049

www.mdpi.com/journal/molecules

Article

\section{Anti-Inflammatory Triterpenoids from the Stems of Microtropis Fokienensis}

I-Hsiao Chen ${ }^{1}$, Ying-Chi Du ${ }^{2}$, Tsong-Long Hwang ${ }^{3}$, I-Fen Chen ${ }^{4}$, Yu-Hsuan Lan ${ }^{5}$, Hsin-Fu Yen ${ }^{6}$, Fang-Rong Chang ${ }^{7,8,9, *}$ and Yang-Chang $\mathrm{Wu}^{5,7,10,11, *}$

1 School of Chinese Medicine for Post Baccalaureate, College of Medicine, I Shou University, Kaohsiung 82445, Taiwan; E-Mail: fantasysp@isu.edu.tw

2 Department of Botanicals, Medical and Pharmaceutical Industry Technology and Development Center, New Taipei City 248, Taiwan; E-Mail: ycdu0626@gmail.com

3 Graduate Institute of Natural Products, College of Medicine, Chang Gung University, Taoyuan 333, Taiwan; E-Mail: ht1@mail.cgu.edu.tw

4

Department of Biomedical Engineering, College of Medicine, I Shou University, Kaohsiung 82445, Taiwan; E-Mail: ifen@isu.edu.tw

5 School of Pharmacy, College of Pharmacy, China Medical University, Taichung 404, Taiwan; E-Mail: lanyh@mail.cmu.edu.tw

6 National Museum of Natural Science, Taichung 404, Taiwan; E-Mail: hfyen@mail.nmns.edu.tw

7 Graduate Institute of Natural Products, College of Pharmacy, Kaohsiung Medical University, Kaohsiung 807, Taiwan

8 Department of Marine Biotechnology and Resources, National Sun Yat-sen University, Kaohsiung 804, Taiwan

9 Cancer Center, Kaohsiung Medical University Hospital, No. 100 Tz-You First Road, Kaohsiung 807, Taiwan

${ }^{10}$ Chinese Medicine Research and Development Center, China Medical University Hospital, Taichung 404, Taiwan

11 Center for Molecular Medicine, China Medical University Hospital, Taichung 404, Taiwan

* Authors to whom correspondence should be addressed; E-Mails: aaronfrc@kmu.edu.tw (F.-R.C.); yachwu@mail.cmu.edu.tw (Y.-C.W.); Tel.: +886-7-312-1101 (ext. 2162) (F.-R.C.); +886-4-2205-3366 (ext. 1012) (Y.-C.W.); Fax: +886-7-311-4773 (F.-R.C.); +886-4-2206-0248 (Y.-C.W.).

Received: 3 March 2014; in revised form: 9 April 2014 / Accepted: 9 April 2014 / Published: 14 April 2014 


\begin{abstract}
Three new ursane- and four new oleanane- type triterpenoids 1-7 were isolated, along with six known compounds 8-13, from the methanolic extract of Microtropis fokienensis. All structures were elucidated by mass and NMR spectroscopic methods. The isolates 4-10 and known compounds 14-17 that were previously isolated from this material were evaluated for anti-inflammatory activity based on effects against superoxide anion generation and elastase release by neutrophils in response to fMLP/CB. 11 $\alpha, 30$ Dihydroxy-2,3-seco-olean-12-en-2,3-dioic anhydride (7) was the first triterpene anhydride from the genus of Microtropis to have the ring A expanded to a seven-membered ring; it showed significant anti-inflammatory activity against superoxide anion generation and elastase release. Unexpectedly, 30-hydroxy-2,3-seco-lup-20(29)-ene-2,3-dioic acid (17) showed the best effect against superoxide anion generation and elastase release with $\mathrm{IC}_{50}$ values of $0.06 \pm 0.01$ and $1.03 \pm 0.35 \mu \mathrm{g} / \mathrm{mL}$, respectively. Compound $\mathbf{1 7}$ had a dioic acid function, and compound 7 had an anhydride function modification in ring A; both showed promising activity in the target assays.
\end{abstract}

Keywords: Microtropis fokienensis; triterpenoids; ursane; oleanane; anti-inflammatory

\title{
1. Introduction
}

Plants belonging to the genus Microtropis are members of the family Celastraceae and are evergreen shrubs that are widely distributed in India, Malaysia, Mainland China, Japan, Central America and Mexico [1]. The chemical constituents of the Microtropis species in Taiwan include sesquiterpenoids, diterpenoids, and triterpenoids [2-5]. Pentacyclic triterpenoids are the dominant constituents within the genus Microtropis and have a basic framework that is similar to that of oleanane, ursane or lupane. Previously, we reported various cytotoxic triterpenoids that worked against cancer cell lines isolated from M. fokienensis and M. japonica [4-6]. There are no prior reports on the anti-inflammatory effects of metabolites from the genus Microtropis. In this study, a bioassay-guided fractionation of a $\mathrm{MeOH}$ extract of $M$. fokienensis stems resulted in the isolation of seven new triterpenoids 1-7 (Figure 1), and six known compounds 8-13. The isolation and structural elucidation of these triterpenes are reported herein. Because of the limited amounts of samples, compounds 4-10 and known compounds, such as 13 $\beta, 28$-epoxy-3 $\beta$-hydroxyurs-11-ene (14) [7,8], 28,30-dihydroxylup20(29)-en-3-one (15) [9], 30-hydroxybetulin (16) [9], and 30-hydroxy-2,3-seco-lup-20(29)-ene-2,3dioic acid (17), which were previously isolated from the stems of $M$. fokienensis [4,6], were selected and evaluated for anti-inflammatory activity based on their inhibition of superoxide anion generation and elastase release by human neutrophils in response to $\mathrm{fMLP} / \mathrm{CB}$.

\section{Results and Discussion}

The dried and powdered stems of $M$. fokienensis were extracted with methanol. The methanolic extract was concentrated, and the residue was partitioned between ethyl acetate and water to provide an organic extract containing triterpenes and an aqueous extract. The organic extract was further 
divided into $n$-hexane and aqueous $\mathrm{MeOH}$ layers using $n$-hexane and $80 \% \mathrm{MeOH}$. The aqueous $\mathrm{MeOH}$ layer was separated using column chromatography and purified by RP-HPLC, to obtain seven new triterpenoids: $3 \beta, 16 \beta$-dihydroxyurs-12-en-11-one (1), 6 $\beta, 12,23$-trihydroxy-11 $\alpha$-methoxyurs-12-en-3-

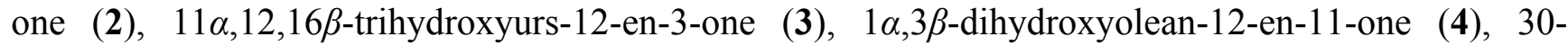

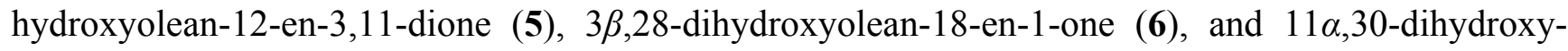
2,3-seco-olean-12-en-2,3-dioic anhydride (7), as well as six known compounds, which were identified by comparing of their NMR data with those reported in literature as $2 \alpha, 3 \beta$-dihydroxyurs-12-en-28-oic acid (8) [10,11], 3 $\beta$-acetoxyurs-12-en-28-oic acid (9) [12], olean-11,13(18)-dien-3 $\beta, 30$-diol (10) [13], 13 $\beta, 28$-epoxy-3 $\beta, 16 \beta$-dihydroxyurs-11-ene (11) [4], $2 \alpha, 3 \beta$-dihydroxyolean-12-en-28-oic acid (12) [14], and olean-12-en-3 $\beta, 30$-diol (13) [15].

Figure 1. Structures of compounds 1-7 and 17.

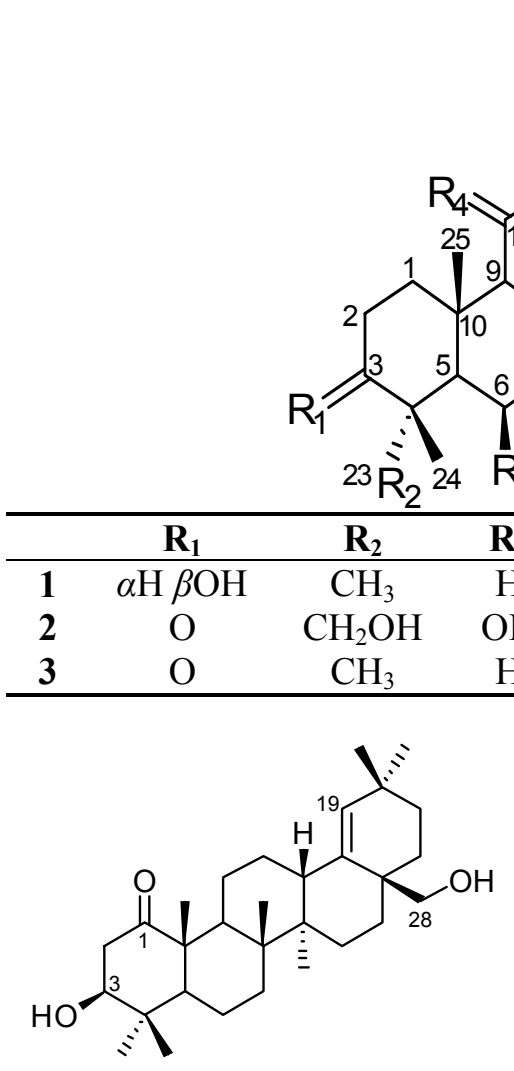

(6)
2324

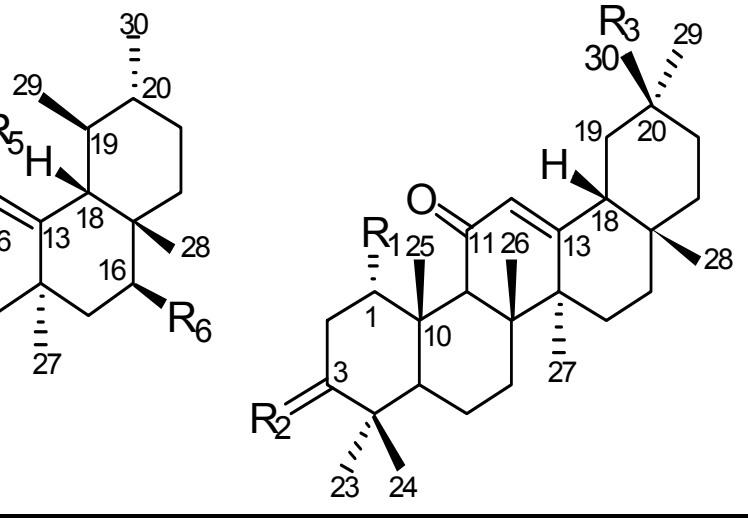

$\begin{array}{lccccccc}\mathbf{R}_{\mathbf{3}} & \mathbf{R}_{\mathbf{4}} & \mathbf{R}_{\mathbf{5}} & \mathbf{R}_{\mathbf{6}} & & \mathbf{R}_{\mathbf{1}} & \mathbf{R}_{\mathbf{2}} & \mathbf{R}_{\mathbf{3}} \\ \mathrm{H} & \mathrm{O} & \mathrm{H} & \mathrm{OH} & \mathbf{4} & \mathrm{OH} & \alpha \mathrm{H} \beta \mathrm{OH} & \mathrm{CH}_{3} \\ \mathrm{OH} & \alpha \mathrm{OCH}_{3} \beta \mathrm{H} & \mathrm{OH} & \mathrm{H} & \mathbf{5} & \mathrm{H} & \mathrm{O} & \mathrm{CH}_{2} \mathrm{OH} \\ \mathrm{H} & \alpha \mathrm{OH} \beta \mathrm{H} & \mathrm{OH} & \mathrm{OH} & & & & \end{array}$

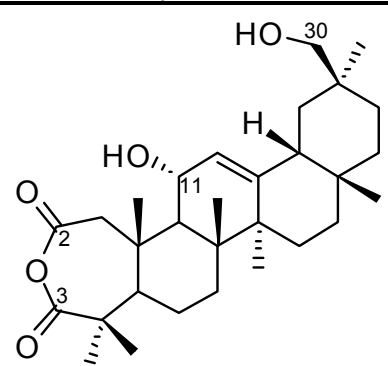

(7)

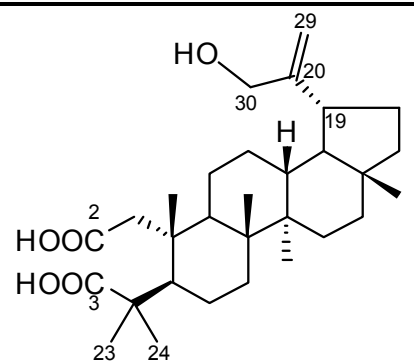

(17)

Compound 1 was obtained as a white amorphous solid. Its IR spectrum showed absorption bands for hydroxyl groups $\left(3425 \mathrm{~cm}^{-1}\right)$ and an $\alpha, \beta$-unsaturated ketone system $\left(1655 \mathrm{~cm}^{-1}\right)$. The molecular formula was determined to be $\mathrm{C}_{30} \mathrm{H}_{48} \mathrm{O}_{3}$ on the basis of the HRESIMS molecular ion at $\mathrm{m} / \mathrm{z} 479.3501$ $\left([\mathrm{M}+\mathrm{Na}]^{+}\right.$, calcd. for 479.3500$)$, which accounted for seven degrees of unsaturation. The ${ }^{1} \mathrm{H}-\mathrm{NMR}$ spectrum exhibited an olefinic proton at $\delta_{\mathrm{H}} 5.85(1 \mathrm{H}, \mathrm{s})$, two methine protons at $\delta_{\mathrm{H}} 3.50(\mathrm{~m})$ and 4.59 (ddd, $J=11.0,5.2$, and $4.4 \mathrm{~Hz}$ ), five tertiary methyl protons at $\delta_{\mathrm{H}} 1.06,1.09,1.26,1.27$, and 1.38 (each $3 \mathrm{H}, \mathrm{s})$, and two secondary methyl protons at $\delta_{\mathrm{H}} 0.80(3 \mathrm{H}, \mathrm{d}, J=6.4 \mathrm{~Hz})$ and $0.91(3 \mathrm{H}, \mathrm{d}, J=6.0 \mathrm{~Hz})$ (Table 1). The ${ }^{13} \mathrm{C}$-NMR spectrum also showed an $\alpha, \beta$-unsaturated ketone system $\left(\delta_{\mathrm{C}} 130.7,163.6\right.$, and 199.3), two oxygenated methines at $\delta_{\mathrm{C}} 64.7$ and 77.9, and eight methyl signals at $\delta_{\mathrm{C}} 16.6,17.0$, 17.6, 18.7, 21.2, 21.9, 23.0, and 28.7 (Table 2). 
Table 1. ${ }^{1} \mathrm{H}-\mathrm{NMR}$ spectroscopic data for compounds $\mathbf{1}-7$ (in $\mathrm{C}_{5} \mathrm{D}_{5} \mathrm{~N}, 400 \mathrm{MHz}$ ).

\begin{tabular}{|c|c|c|c|c|c|c|c|}
\hline No. & 1 & 2 & $3^{a}$ & 4 & 5 & 6 & 7 \\
\hline \multirow{2}{*}{1} & $1.20(\mathrm{~m}, \alpha)$ & $1.80(\mathrm{~m}, \alpha)$ & $2.04(\mathrm{~m}, \alpha)$ & \multirow{2}{*}{$5.37(\mathrm{~s})$} & $1.55(\mathrm{~m}, \alpha)$ & & $3.14(\mathrm{~d}, 17.6)$ \\
\hline & $3.14(\mathrm{dt}, 13.6,3.6, \beta)$ & $2.84(\mathrm{~m}, \beta)$ & $3.04(\mathrm{~m}, \beta)$ & & $3.20(\mathrm{~m}, \beta)$ & & $3.33(\mathrm{~d}, 17.6)$ \\
\hline \multirow{2}{*}{2} & $1.88(\mathrm{~m}, \alpha)$ & \multirow{3}{*}{$2.52(\mathrm{~m}, \alpha) 2.91(\mathrm{~m}, \beta)$} & $2.55(\mathrm{~m}, \alpha)$ & $2.33(\mathrm{dt}, 13.6,3.6, \alpha)$ & $2.46(\mathrm{~m}, \alpha)$ & $2.74(\mathrm{dd}, 11.6,4.8, \alpha)$ & \\
\hline & $2.04(\mathrm{~m}, \beta)$ & & $2.62(\mathrm{~m}, \beta)$ & $2.48(\mathrm{dd}, 13.6,12.0, \beta)$ & $2.69(\mathrm{~m}, \beta)$ & $3.50(\mathrm{dd}, 12.0,11.6, \beta)$ & \\
\hline 3 & $3.50(\mathrm{~m}, \alpha)$ & & & $4.43(\mathrm{dd}, 12.0,3.6, \alpha)$ & & $3.75(\mathrm{dd}, 12.0,4.8, \alpha)$ & \\
\hline 5 & $0.87(\mathrm{~m})$ & 2.58 (brs) & $1.59(\mathrm{~m})$ & 1.71 & $1.41(\mathrm{~m})$ & $0.98(\mathrm{dd}, 11.2,2.4)$ & $1.96(\mathrm{~m})$ \\
\hline 6 & $1.56(2 \mathrm{H}, \mathrm{m})$ & $4.94(\mathrm{brs}, \alpha)$ & $1.44(2 \mathrm{H}, \mathrm{m})$ & $1.61(\mathrm{~m}) 1.72(\mathrm{~m})$ & $1.43(2 \mathrm{H})$ & $1.50(\mathrm{~m}) 1.58(\mathrm{~m})$ & $1.58(\mathrm{~m}) 1.67(\mathrm{~m})$ \\
\hline 7 & $1.71(\mathrm{~m}, \alpha) 1.40(\mathrm{~m}, \beta)$ & $1.98(\mathrm{~m}, \alpha) 1.86(\mathrm{~m}, \beta)$ & $1.66(\mathrm{~m}, \alpha) 1.46(\mathrm{~m}, \beta)$ & $1.74(\mathrm{~m}, \alpha) 1.35(\mathrm{~m}, \beta)$ & $1.30(\mathrm{~m}) 1.60(\mathrm{~m})$ & $1.26(\mathrm{dd}, 12.0,3.2) 1.40(\mathrm{~m})$ & $1.33(\mathrm{~m}) 1.73(\mathrm{~m})$ \\
\hline 9 & $2.55(\mathrm{~s})$ & $2.36(\mathrm{~d}, 10.0)$ & $2.19(\mathrm{~d}, 10.0)$ & $3.87(\mathrm{~s})$ & $2.55(\mathrm{~s})$ & $2.27(\mathrm{dd}, 12.0,2.0)$ & $2.19(\mathrm{~d}, 11.2)$ \\
\hline 11 & & $4.82(\mathrm{~d}, 10.0, \beta)$ & $4.58(\mathrm{~d}, 9.5, \beta)$ & & & $1.22(\mathrm{~m}) 1.93(\mathrm{~m})$ & $4.91(\mathrm{dd}, 10.8,2.4)$ \\
\hline 12 & $5.85(\mathrm{~s})$ & & & $5.76(\mathrm{~s})$ & $5.83(\mathrm{~s})$ & $\begin{array}{l}1.43(\mathrm{~m}) \\
1.51(\mathrm{~m})\end{array}$ & $5.49(\mathrm{~d}, 2.0)$ \\
\hline 13 & & & & & & $2.40(\mathrm{~m})$ & \\
\hline 15 & $1.79(\mathrm{~m}, \alpha) 2.11(\mathrm{~m}, \beta)$ & $1.38(2 \mathrm{H}, \mathrm{m})$ & $1.71(\mathrm{~m}, \alpha) 2.13(\mathrm{~m}, \beta)$ & 1.071 .75 & $1.09(\mathrm{~m}) 1.72(\mathrm{~m})$ & $1.13(\mathrm{~m}) 1.89(\mathrm{~m})$ & $0.95(\mathrm{~m}) 1.74(\mathrm{~m})$ \\
\hline \multirow{2}{*}{16} & \multirow{2}{*}{$4.59(\mathrm{ddd}, 11.0,5.2,4.4)$} & \multirow{2}{*}{$1.43(2 \mathrm{H}, \mathrm{m})$} & \multirow{2}{*}{$4.63(\mathrm{~m}, \alpha)$} & $1.97(\mathrm{td}, 13.6,4.4, \alpha)$ & $2.10(\mathrm{td}, 13.6,4.4, \alpha)$ & $1.32(\mathrm{~m})$ & $0.89(\mathrm{~m})$ \\
\hline & & & & $0.83(\mathrm{~m}, \beta)$ & $0.92(\mathrm{dt}, 13.6,2.0, \beta)$ & $2.21(\mathrm{~m})$ & $2.04(\mathrm{td}, 13.2,4.0)$ \\
\hline 18 & $1.79(\mathrm{~d}, 11.2)$ & $2.90(\mathrm{~m})$ & $3.10(\mathrm{~d}, 11.5)$ & $2.11(\mathrm{dd}, 13.6,4.0)$ & $2.30(\mathrm{dd}, 13.4,4.4)$ & & $2.21(\mathrm{dd}, 10.8,4.4)$ \\
\hline 19 & $1.55(\mathrm{~m})$ & $1.81(\mathrm{~m})$ & $1.68(\mathrm{~m})$ & $0.79(\mathrm{~m}) 1.53(\mathrm{~m})$ & $1.52(\mathrm{~m}) 1.69(\mathrm{~m})$ & $5.11(\mathrm{~s})$ & $1.60(\mathrm{~m}) 1.75(\mathrm{~m})$ \\
\hline 20 & $0.91(\mathrm{~m})$ & $2.52(\mathrm{~m})$ & $1.80(\mathrm{~m})$ & & & & \\
\hline 21 & $1.46(\mathrm{~m}, 2 \mathrm{H})$ & $1.38(2 \mathrm{H}, \mathrm{m})$ & $1.51(\mathrm{~m}) 1.59(\mathrm{~m})$ & $1.06(\mathrm{~m}) 1.34(\mathrm{~m})$ & $1.40(\mathrm{~m}) 1.69(\mathrm{~m})$ & $1.38(\mathrm{~m}) 1.70(\mathrm{~m})$ & $1.32(\mathrm{~m}) 1.70(\mathrm{~m})$ \\
\hline \multirow{2}{*}{22} & $1.13(\mathrm{~d}, 3.2, \alpha)$ & $0.80(\mathrm{~m})$ & $1.29(\mathrm{~m})$ & $1.22(\mathrm{~m})$ & $1.28(\mathrm{~m})$ & $1.39(\mathrm{~m})$ & $1.32(\mathrm{~m})$ \\
\hline & $2.57(\mathrm{dt}, 13.6,3.2, \beta)$ & $1.96(\mathrm{~m})$ & 2.68 (brd, 13.0) & $1.43(\mathrm{~m})$ & $1.56(\mathrm{~m})$ & $2.36(\mathrm{~m})$ & $1.70(\mathrm{~m})$ \\
\hline 23 & $1.26(\mathrm{~s})$ & $\begin{array}{c}3.93(\mathrm{~d}, 10.4) 4.47(\mathrm{~d}, \\
10.4)\end{array}$ & $1.20(\mathrm{~s})$ & $1.38(\mathrm{~s})$ & $1.08(\mathrm{~s})$ & $1.18(\mathrm{~s})$ & $1.40(\mathrm{~s})$ \\
\hline 24 & $1.09(\mathrm{~s})$ & $1.70(\mathrm{~s})$ & $1.13(\mathrm{~s})$ & $1.18(\mathrm{~s})$ & $1.18(\mathrm{~s})$ & $1.22(\mathrm{~s})$ & $1.47(\mathrm{~s})$ \\
\hline 25 & $1.38(\mathrm{~s})$ & $1.92(\mathrm{~s})$ & $1.27(\mathrm{~s})$ & $1.46(\mathrm{~s})$ & $1.35(\mathrm{~s})$ & $1.29(\mathrm{~s})$ & $1.39(\mathrm{~s})$ \\
\hline 26 & $1.27(\mathrm{~s})$ & $1.84(\mathrm{~s})$ & $1.30(\mathrm{~s})$ & $1.22(\mathrm{~s})$ & $1.12(\mathrm{~s})$ & $1.04(\mathrm{~s})$ & $1.01(\mathrm{~s})$ \\
\hline 27 & $1.47(\mathrm{~s})$ & $1.31(\mathrm{~s})$ & $1.54(\mathrm{~s})$ & $1.36(\mathrm{~s})$ & $1.37(\mathrm{~s})$ & $0.94(\mathrm{~s})$ & $1.27(\mathrm{~s})$ \\
\hline 28 & $1.06(\mathrm{~s})$ & $0.98(\mathrm{~s})$ & $1.26(\mathrm{~s})$ & $0.85(\mathrm{~s})$ & $0.85(\mathrm{~s})$ & $3.81(\mathrm{~d}, 10.4) 4.02(\mathrm{~d}, 10.4)$ & $0.86(\mathrm{~s})$ \\
\hline 29 & $0.80(\mathrm{~d}, 6.4)$ & $1.26(\mathrm{~d}, 6.4)$ & $1.18(\mathrm{~d}, 6.5)$ & $0.81(\mathrm{~s})$ & $1.17(\mathrm{~s})$ & $1.06(\mathrm{~s})$ & $1.16(\mathrm{~s})$ \\
\hline 30 & $0.91(\mathrm{~d}, 6.0)$ & $0.97(\mathrm{~d}, 7.2)$ & $0.95(\mathrm{~d}, 6.5)$ & $0.83(\mathrm{~s})$ & $\begin{array}{l}3.74(\mathrm{~d}, 10.4) \\
3.80(\mathrm{~d}, 10.4) \\
\end{array}$ & $1.07(\mathrm{~s})$ & $\begin{array}{l}3.74(\mathrm{~d}, 10.4) \\
3.82(\mathrm{~d}, 10.4) \\
\end{array}$ \\
\hline
\end{tabular}

${ }^{a}$ Measured in $\mathrm{C}_{5} \mathrm{D}_{5} \mathrm{~N}, 500 \mathrm{MHz}$. 
Table 2. ${ }^{13} \mathrm{C}-\mathrm{NMR}$ Spectroscopic Data for Compounds 1-7 (in $\mathrm{C}_{5} \mathrm{D}_{5} \mathrm{~N}, 100 \mathrm{MHz}$ ).

\begin{tabular}{|c|c|c|c|c|c|c|c|}
\hline No. & 1 & 2 & $3^{a}$ & 4 & 5 & 6 & 7 \\
\hline 1 & 39.8 & 40.5 & 42.5 & 72.3 & 40.0 & 212.9 & 49.6 \\
\hline 2 & 28.1 & 36.1 & 35.1 & 35.5 & 34.4 & 45.4 & 170.6 \\
\hline 3 & 77.9 & 216.0 & 217.2 & 72.3 & 215.9 & 79.0 & 182.0 \\
\hline 4 & 39.8 & 54.7 & 48.3 & 40.1 & 47.8 & 40.1 & 45.4 \\
\hline 5 & 55.3 & 49.2 & 56.1 & 47.8 & 55.1 & 54.9 & 55.2 \\
\hline 6 & 18.0 & 67.8 & 20.5 & 17.8 & 19.0 & 18.1 & 20.7 \\
\hline 7 & 33.2 & 41.6 & 34.4 & 32.8 & 32.1 & 34.4 & 33.4 \\
\hline 8 & 45.7 & 42.6 & 43.5 & 45.2 & 45.3 & 40.7 & 41.1 \\
\hline 9 & 61.3 & 46.6 & 53.8 & 53.8 & 61.2 & 42.8 & 45.9 \\
\hline 10 & 37.4 & 37.8 & 38.5 & 42.1 & 37.0 & 53.5 & 38.5 \\
\hline 11 & 199.3 & 77.3 & 70.2 & 200.9 & 198.9 & 24.4 & 74.5 \\
\hline 12 & 130.7 & 145.0 & 148.4 & 128.6 & 128.4 & 26.7 & 121.4 \\
\hline 13 & 163.6 & 116.5 & 113.2 & 169.7 & 170.6 & 39.6 & 149.8 \\
\hline 14 & 45.8 & 41.4 & 44.2 & 44.0 & 43.7 & 43.7 & 43.1 \\
\hline 15 & 37.1 & 27.6 & 37.8 & 26.7 & 26.7 & 27.8 & 25.8 \\
\hline 16 & 64.7 & 28.0 & 65.9 & 26.5 & 26.9 & 31.3 & 27.5 \\
\hline 17 & 39.2 & 33.7 & 39.5 & 32.5 & 32.5 & 32.5 & 32.9 \\
\hline 18 & 60.7 & 47.5 & 49.9 & 47.6 & 47.3 & 140.7 & 47.2 \\
\hline 19 & 39.1 & 41.3 & 41.9 & 45.2 & 40.8 & 132.6 & 41.6 \\
\hline 20 & 39.4 & 40.0 & 40.7 & 31.0 & 36.0 & 32.5 & 36.1 \\
\hline 21 & 30.8 & 31.6 & 31.8 & 34.5 & 29.9 & 33.4 & 30.0 \\
\hline 22 & 35.4 & 42.2 & 36.8 & 36.7 & 36.4 & 31.1 & 36.6 \\
\hline 23 & 28.7 & 66.8 & 27.5 & 28.8 & 21.5 & 28.6 & 28.2 \\
\hline 24 & 16.6 & 20.5 & 22.1 & 16.2 & 26.5 & 16.6 & 23.3 \\
\hline 25 & 17.0 & 17.6 & 16.9 & 18.0 & 15.9 & 16.1 & 17.7 \\
\hline 26 & 18.7 & 20.3 & 18.9 & 19.1 & 18.5 & 17.0 & 17.1 \\
\hline 27 & 21.9 & 24.0 & 26.0 & 23.6 & 23.4 & 15.1 & 25.5 \\
\hline 28 & 23.0 & 28.9 & 23.6 & 28.8 & 28.7 & 63.6 & 28.4 \\
\hline 29 & 17.6 & 17.4 & 17.8 & 33.0 & 28.2 & 31.4 & 28.2 \\
\hline 30 & 21.2 & 21.5 & 22.0 & 23.5 & 65.3 & 29.7 & 65.6 \\
\hline $\mathrm{OCH}_{3}$ & & 51.4 & & & & & \\
\hline
\end{tabular}

${ }^{a}$ Measured in $\mathrm{C}_{5} \mathrm{D}_{5} \mathrm{~N}, 125 \mathrm{MHz}$.

Therefore, 1 was suggested to have an urs-12-ene frame and the $\alpha, \beta$-unsaturated ketone system in ring $\mathrm{C}$ was similar to $3 \beta$-hydroxyurs-12-en-11-one, except for the presence of one more oxymethine [16-18]. The MS fragmentations at $m / z$ 248, where each bond was cleaved at the $\alpha, \beta$-unsaturated ketone system in ring $\mathrm{C}$, indicated that the other hydroxyl group was seemed to be located in either ring D or E. (Figure 2) [19]. The hydroxyl group was assigned to C-16, because of the low field shifted signals of $\delta_{\mathrm{C}} 60.7$ (C-18), and the HMBC correlation of H-18 $\left(\delta_{\mathrm{H}} 1.79\right)$ and H-15 $\left(\delta_{\mathrm{H}} 2.11\right) / \mathrm{C}-16\left(\delta_{\mathrm{C}} 64.7\right)$ (Figure 3$)$. The NOESY experiment showed the NOE effect of H-3 and H-16 with H-5 and H-27 (Figure 4), respectively, indicating that the relative stereochemistry of the two hydroxyl groups at $\mathrm{C}-3$ and $\mathrm{C}-16$ were resolved as the $\beta$ form. Therefore, the structure of 1 was determined and named $3 \beta, 16 \beta$-dihydroxyurs-12-en-11-one. 
Figure 2. Mass fragmentation patterns of $\mathbf{1}$.
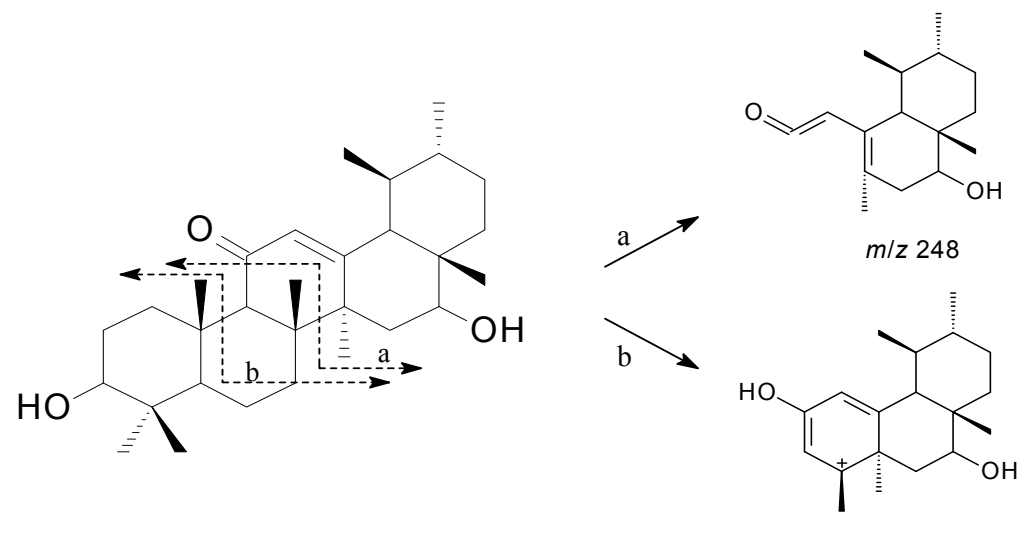

$m / z 289$

Figure 3. COSY and HMBC correlations of 1-7.

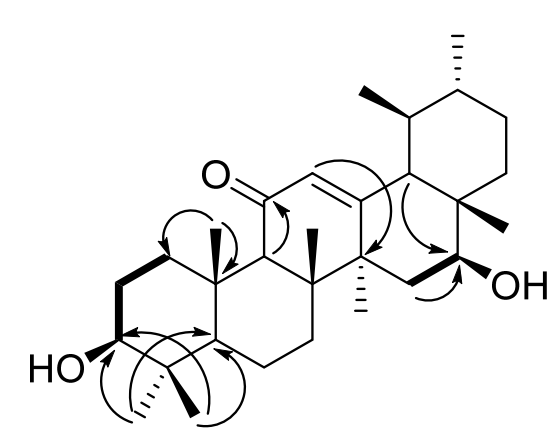

(1)

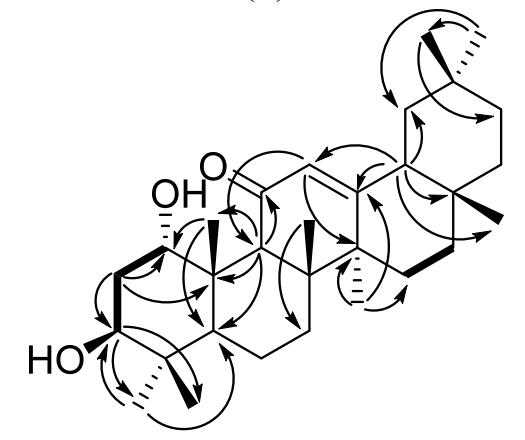

(4)

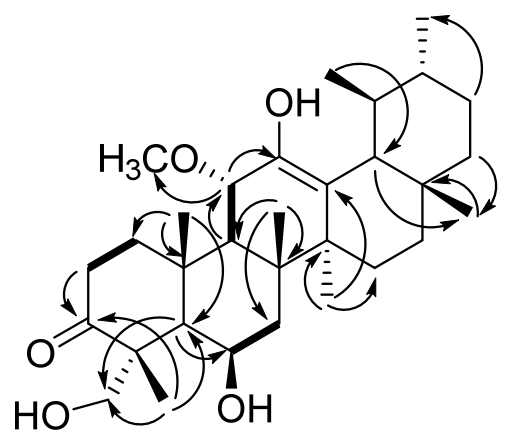

(2)

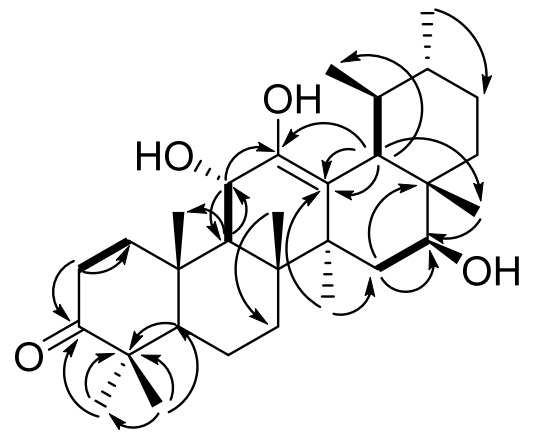

(3)

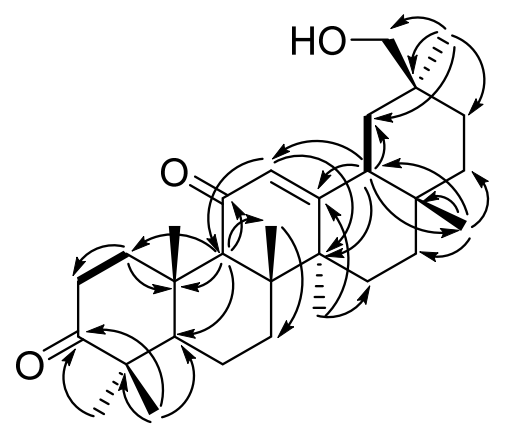

(5)

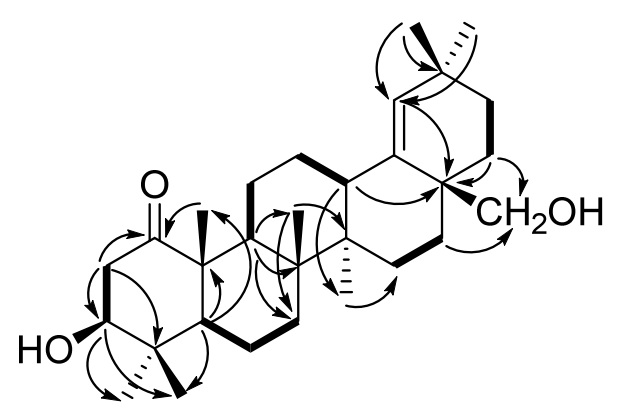

(6)

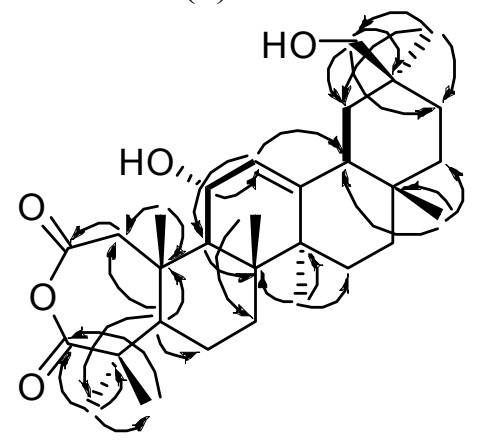

(7) 
Figure 4. NOESY correlations of 1-7.

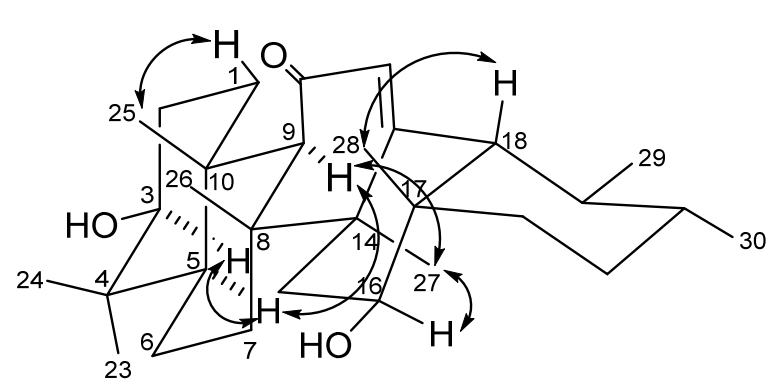

(1)

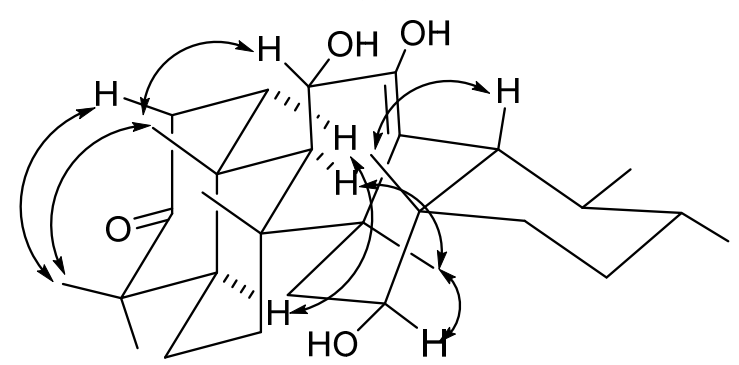

(3)

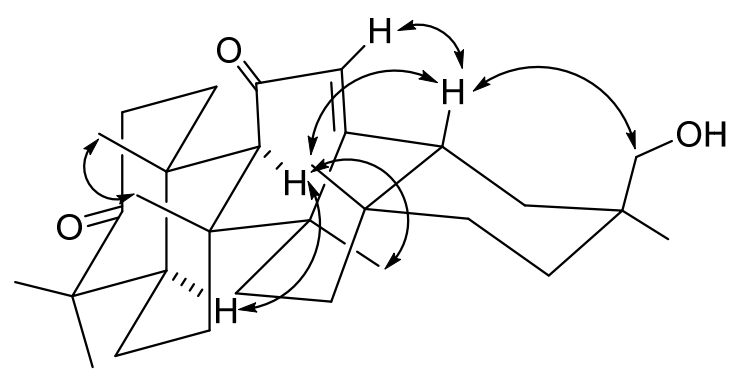

(5)

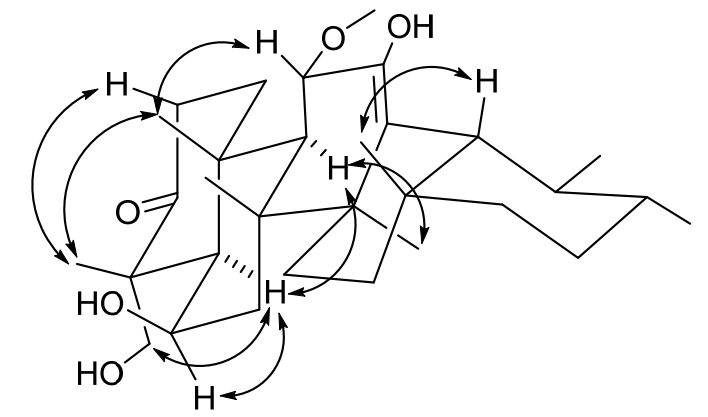

(2)

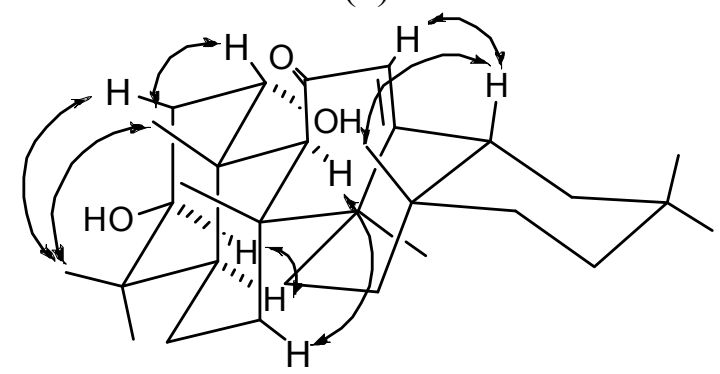

(4)

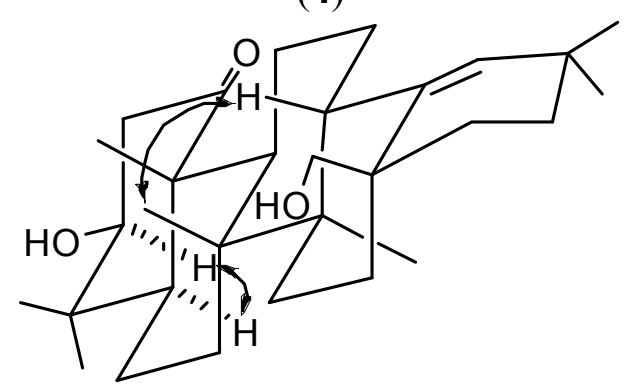

(6)

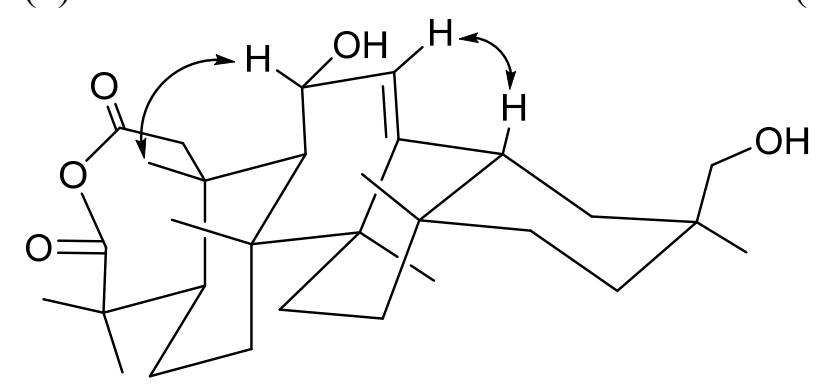

(7)

Compound $\mathbf{2}$ was isolated as a white amorphous powder. HRESIMS indicated a molecular formula of $\mathrm{C}_{31} \mathrm{H}_{50} \mathrm{O}_{5}\left(\mathrm{~m} / z 525.3556[\mathrm{M}+\mathrm{Na}]^{+}\right.$, calcd. for 525.3559). It showed absorption bands in its IR spectrum at 3446, 1694, and $1649 \mathrm{~cm}^{-1}$ for hydroxyl, carbonyl, and olefinic functions. The ${ }^{1} \mathrm{H}-\mathrm{NMR}$ spectrum of 2 exhibited signals due to five tertiary methyls $\left(\delta_{\mathrm{H}} 0.98,1.31,1.70,1.84\right.$ and 1.92$)$, two secondary methyls $\left[\delta_{\mathrm{H}} 0.97(\mathrm{~d}, J=7.2 \mathrm{~Hz})\right.$ and $\left.1.26(\mathrm{~d}, J=6.4 \mathrm{~Hz})\right]$, a methoxyl $\left(\delta_{\mathrm{H}} 3.35\right)$, a hydroxymethylene $\left[\delta_{\mathrm{H}} 3.93(\mathrm{~d}, J=10.4 \mathrm{~Hz})\right.$ and $\left.4.47(\mathrm{~d}, J=10.4 \mathrm{~Hz})\right]$, and two oxygenated methines $\left[\delta_{\mathrm{H}} 4.82(\mathrm{~d}, J=10.0 \mathrm{~Hz})\right.$ and 4.94 (brs)] (Table 1). The ${ }^{13} \mathrm{C}-\mathrm{NMR}$ and the DEPT spectra of 2 suggested the presence of a cyclic ketone at $\delta_{\mathrm{C}} 216.0$, two olefinic carbons at $\delta_{\mathrm{C}} 116.5$ and 145.0, two oxygenated carbons at $\delta_{\mathrm{C}} 67.8$ and 77.3 , a methylene carbon at $\delta_{\mathrm{C}} 66.8$, and a methoxy carbon 
at $\delta_{\mathrm{C}} 51.4$ (Table 2). Based on the molecular formula of $\mathrm{C}_{31} \mathrm{H}_{50} \mathrm{O}_{5}$, the degrees of unsaturation of 2 were determined to be seven, including one ketone and double bond. This spectral evidence suggested that 2 was a derivative of the pentacyclic triterpenoid urs-12-en-3-one, with a tetrasubstituted double bond, two oxygenated methines, one hydroxymethylene, and one methoxy moiety [5]. Based on the evidence of the HMBC spectrum (Figure 3), a secondary hydroxyl, a methoxy, and a tertiary hydroxyl groups were deemed to be attached at C-6, C-11, and C-12. The chemical shifts of C-4 $\left(\delta_{\mathrm{C}} 54.7\right)$ and $\mathrm{CH}_{3}-24\left(\delta_{\mathrm{C}} 20.5\right)$ led to the assignment of the $\mathrm{CH}_{2} \mathrm{OH}$ unit at the $\mathrm{C}-23 \alpha$ position [20]. The NOESY (Figure 4) correlations illustrated the stereochemistry of 2 . Therefore, the structure of the new compound 2 was determined to be $6 \beta, 12,23$-trihydroxy-11 $\alpha$-methoxyurs-12-en-3-one.

Compound 3, isolated as white amorphous powder, showed IR absorption bands for hydroxyl $\left(3418 \mathrm{~cm}^{-1}\right)$ and carbonyl $\left(1694 \mathrm{~cm}^{-1}\right)$ groups. The molecular formula was determined as $\mathrm{C}_{30} \mathrm{H}_{48} \mathrm{O}_{4}$ based on HRESIMS (495.3450 [M+Na] $]^{+}$, calcd. for 495.3452), corresponding to seven degrees of unsaturation. The ${ }^{1} \mathrm{H}-\mathrm{NMR}$ spectrum of $\mathbf{3}$ exhibited signals that were due to six tertiary methyls $\left[\delta_{\mathrm{H}} 1.13,1.20,1.26,1.27,1.30\right.$, and 1.54$]$, two secondary methyls $\left[\delta_{\mathrm{H}} 0.95(\mathrm{~d}, J=6.5 \mathrm{~Hz})\right.$ and $1.18(\mathrm{~d}$, $J=6.5 \mathrm{~Hz})$ ], and two oxygenated methines $\left[\delta_{\mathrm{H}} 4.58(\mathrm{~d}, J=9.5 \mathrm{~Hz})\right.$ and $\left.4.63(\mathrm{~m})\right]$ (Table 1). The ${ }^{13} \mathrm{C}$-NMR spectrum indicated that 3 was constituted by 30 carbons including a cyclic ketone $\left[\delta_{\mathrm{C}}\right.$ 217.2], two olefinic carbons [ $\delta_{\mathrm{C}} 113.2$ and 148.4], and two oxygenated carbons [ $\delta_{\mathrm{C}} 65.9$ and 70.2] (Table 2). This spectral evidence suggested that 3 was an urs-12-en-3-one derivative with a tetrasubstituted double bond, and two oxygen-bearing functional groups [5]. The partial structure of $\mathbf{3}$ was solved by the HMBC correlations of the eight methyl groups. Detailed analysis of other correlations in the HMBC spectrum determined the locations of the followings substituents: three hydroxyl groups were located at C-11, C-12, and C-16, and a double bond between C-12 and C-13 (Figure 3). The stereochemistry of $\mathbf{3}$ was further established from the NOESY spectrum (Figure 4), and the structure $11 \alpha, 12,16 \beta$-trihydroxyurs-12-en-3-one was assigned.

Compound 4 was assigned a molecular formula of $\mathrm{C}_{30} \mathrm{H}_{48} \mathrm{O}_{3}$ and seven degrees of unsaturation, as deduced from the HRESIMS $\left(\mathrm{m} / z\right.$ 479.3501 $[\mathrm{M}+\mathrm{Na}]^{+}$, calcd. for 479.3503$)$ and ${ }^{13} \mathrm{C}-\mathrm{NMR}$ spectra. The IR spectrum showed a hydroxyl group $\left(3421 \mathrm{~cm}^{-1}\right)$ and an $\alpha, \beta$-unsaturated ketone system $\left(1652 \mathrm{~cm}^{-1}\right)$. The ${ }^{13} \mathrm{C}-\mathrm{NMR}$ and DEPT spectra displayed 30 carbon signals, with signals for two carbons bearing oxygen observed at $\delta_{\mathrm{C}} 72.3(2 \times \mathrm{C})$ and signals for an $\alpha, \beta$-unsaturated ketone system observed at $\delta_{\mathrm{C}} 128.6,169.7$, and 200.9. A comparison of the ${ }^{1} \mathrm{H}$ and ${ }^{13} \mathrm{C}-\mathrm{NMR}$ spectra data of 4 with those of 1 (Tables 1 and 2) revealed that $\mathbf{4}$ differed from $\mathbf{1}$ in the presence of eight tertiary methyls and had an oleanane skeleton [21]. The substituted functions and planar structure of 4 were established in extensive interpretation of its 2D NMR spectra (Figure 3). Based on the NOESY spectrum (Figure 4), the configurations of the H-1 and H-3 were assigned to be $\beta$ and $\alpha$ orientation. Therefore, the structure of 4 was determined to be $1 \alpha, 3 \beta$-dihydroxyolean-12-en-11-one.

The IR spectrum of compound 5 showed a hydroxyl group (3441 $\left.\mathrm{cm}^{-1}\right)$, a carbonyl group $\left(1697 \mathrm{~cm}^{-1}\right)$, and an $\alpha, \beta$-unsaturated ketone system $\left(1648 \mathrm{~cm}^{-1}\right)$. The molecular formula $\mathrm{C}_{30} \mathrm{H}_{46} \mathrm{O}_{3}$ was established by HRESIMS ( $\mathrm{m} / \mathrm{z} 477.3344[\mathrm{M}+\mathrm{Na}]^{+}$, calcd. for 477.3341), implying eight degrees of unsaturation. The characteristic ${ }^{1} \mathrm{H}$ and ${ }^{13} \mathrm{C}$-NMR data of 5 (Tables 1 and 2) indicated the presence of a carbonyl and a hydroxymethylene on the 12-oleanen-11-one chemical frame instead of two hydroxymethines in 4 [19]. The key HMBC were shown on Figure 3 in order to determine the locations of the substituents and the planar structure. Based on this evidence and the NOESY 
(Figure 4), a primary alcohol group was deemed to be located at C-30. Therefore, the structure of compound 5 was determined to be 30-hydroxyolean-12-en-3,11-dione.

The molecular formula of 6 was assigned as $\mathrm{C}_{30} \mathrm{H}_{48} \mathrm{O}_{3}\left(\mathrm{~m} / \mathrm{z} 479.3501[\mathrm{M}+\mathrm{Na}]^{+}\right.$, calcd. for 479.3504) by HRESIMS. The IR spectrum indicated the occurrence of hydroxyl $\left(3376 \mathrm{~cm}^{-1}\right)$, carbonyl $\left(1698 \mathrm{~cm}^{-1}\right)$, and olefinic $\left(1632 \mathrm{~cm}^{-1}\right)$ moieties. The ${ }^{1} \mathrm{H}$ and ${ }^{13} \mathrm{C}$-NMR spectra of 6 exhibited signals (Tables 1 and 2) for seven tertiary methyls, a hydroxymethylene $\left[\delta_{\mathrm{H}} 3.81\right.$ and $4.02(1 \mathrm{H}$ each, $\left.J=10.4 \mathrm{~Hz}) ; \delta_{\mathrm{C}} 63.6\right]$, an oxygenated-methine $\left[\delta_{\mathrm{H}} 3.75(1 \mathrm{H}, \mathrm{m}) ; \delta_{\mathrm{C}} 79.0\right]$, and a trisubstituted double bond $\left[\delta_{\mathrm{H}} 5.11(1 \mathrm{H}\right.$, brs $)$; $\delta_{\mathrm{C}} 132.6$ and 140.7]. The ${ }^{1} \mathrm{H}$ and ${ }^{13} \mathrm{C}-\mathrm{NMR}$ spectra and 2D NMR experiments revealed features of the $\Delta^{18}$ oleanane-type triterpene with one carbonyl and two hydroxyl groups [22-25]. The characteristic signals including an upfield shift of C-29 ( $\triangle 2 \mathrm{ppm})$ and a downfield shift of C-30 ( $\triangle 7 \mathrm{ppm})$ in the ${ }^{13} \mathrm{C}-\mathrm{NMR}$ spectrum confirmed that 6 is an $\Delta^{18}$ oleanane-type triterpene [26]. The COSY, HMQC, and HMBC determined the locations of the substituents and the planar structure, and a carbonyl, an oxygenated-methine, and a hydroxymethylene were assigned at C-1, C-3, and C-28 (Figure 3). The coupling constants of the oxygenated methine at $\delta_{\mathrm{H}} 3.75(J=12.0,4.8 \mathrm{~Hz})$ indicated a $3 \beta$-hydroxyl group [27]. Accordingly, compound 6 was determined to be 3 $\beta, 28$-dihydroxyolean-18-en-1-one.

Compound 7 was isolated as a white amorphous powder. Its molecular formula, $\mathrm{C}_{30} \mathrm{H}_{46} \mathrm{O}_{5}$, was determined by HRESIMS ( $\mathrm{m} / \mathrm{z} 509.3243[\mathrm{M}+\mathrm{Na}]^{+}$, calcd. for 509.3246), corresponding to eight degrees of unsaturation. The IR spectrum showed absorption bands for hydroxyl $\left(3426 \mathrm{~cm}^{-1}\right)$ and carbonyl $\left(1712 \mathrm{~cm}^{-1}\right.$, broad) functional groups. The ${ }^{1} \mathrm{H}-\mathrm{NMR}$ spectrum revealed signals due to an olefinic proton $\left[\delta_{\mathrm{H}} 5.49(\mathrm{~d}, J=2.0 \mathrm{~Hz})\right]$, seven tertiary methyls $\left(\delta_{\mathrm{H}} 0.86,1.01,1.16,1.27,1.39,1.40\right.$, and 1.47), a hydroxymethylene $\left[\delta_{\mathrm{H}} 3.74(\mathrm{~d}, J=10.4 \mathrm{~Hz}), 3.82(\mathrm{~d}, J=10.4 \mathrm{~Hz})\right]$, and an oxygenated methines $\left[\delta_{\mathrm{H}} 4.91(\mathrm{dd}, J=10.8,2.4 \mathrm{~Hz})\right]$ (Table 1). The ${ }^{13} \mathrm{C}-\mathrm{NMR}$ spectrum indicated the presence of 30 carbon atoms, including one trisubstituted double bond $\left(\delta_{\mathrm{C}} 121.4\right.$ and 149.8), seven methyls, nine methylenes (one oxygenated), four methines (one oxygenated), and eight quaternary carbons (two carbonyl carbons) (Table 2). Previous studies [28,29] showed two carbonyls groups at $\delta_{\mathrm{C}} 170.6$ and 182.0 together with the absence of absorption bands for carboxylic groups in the IR spectrum, which indicated the presence of an anhydride moiety in the molecule. Eight degrees of unsaturation were implied by the molecular formula. As well as two carbonyls and one olefinic group, compound 7 possesses a pentacyclic system. This data indicated that this compound belongs to the olean-12-ene family of triterpenoids, with an embedded anhydride function and two additional hydroxyl groups $[28,29]$. In the HMBC spectrum of 7 , the correlations for $\mathrm{H}-11\left(\delta_{\mathrm{H}} 4.91\right) / \mathrm{C}-12\left(\delta_{\mathrm{C}} 121.4\right)$, and for H-12 $\left(\delta_{\mathrm{H}} 5.49\right) / \mathrm{C}-9\left(\delta_{\mathrm{C}} 45.9\right)$ and C-18 $\left(\delta_{\mathrm{C}} 47.2\right)$ indicated that a hydroxyl group was attached at C-11. The HMBC correlations of both H-29 and H-30 with C-19 and C-20 also indicated that the hydroxymethylene group was attached at C-20. On the basis of the previous study [30], the chemical shift of the C-29 (equatorial) hydroxymethylene group resonated at around $75 \mathrm{ppm}$ and the value of the C-30 (axial) methyl group was found at around $20 \mathrm{ppm}$ in the ${ }^{13} \mathrm{C}-\mathrm{NMR}$ spectrum. In contrast, the chemical shift of the C-30 hydroxymethylene group appeared at around 67 ppm, while the C-29 methyl group appeared at around $28 \mathrm{ppm}$. Therefore, the remaining hydroxyl group in 7 was placed at C-30. Detailed analysis of the correlations of the HMBC spectrum gave the location of the anhydride at C-2 and C-3 (Figure 3). The orientation of a hydroxyl group at C-11 was assumed to be $\alpha$ on the basis of the NOESY correlations between H-11 and H-25. In according with all these data, the structure of 7 was established as 11 $\alpha, 30$-dihydroxy-2,3-seco-olean-12-en-2,3-dioic anhydride. 
Although a triterpene anhydride has been reported from species of the Celastraceae family, $11 \alpha, 30$ dihydroxy-2,3-seco-olean-12-en-2,3-dioic anhydride (7) represents the first example of a triterpene anhydride with the ring A expanding to a seven-membered ring from the genus of Microtropis.

As mentioned in the section of introduction, several cytotoxic triterpenoids have been reported to inhibit various cancer cell lines isolated from M. fokienensis and M. japonica [4-6], but there are no prior reports of the anti-inflammatory effects of metabolites from the genus Microtropis. A target assay based on effects against superoxide anion generation and elastase release by human neutrophils in response to $\mathrm{fMLP} / \mathrm{CB}$ was carried out. Due to the limited amounts of samples, 4-10 and known compounds, such as 13 $\beta, 28$-epoxy-3 $\beta$-hydroxyurs-11-ene (14), 28,30-dihydroxylup-20(29)-en-3-one (15), 30-hydroxybetulin (16), and 30-hydroxy-2,3-seco-lup-20(29)-ene-2,3-dioic acid (17), which were isolated previously from the stems of M. fokienensis [6], were selected and evaluated (Table 3). Compounds $\mathbf{7}$ and $\mathbf{1 7}$ showed significant anti-inflammatory activity against superoxide anion generation and elastase release, with $\mathrm{IC}_{50}$ values of $2.10 \pm 0.13 / 2.93 \pm 0.27$ and $0.06 \pm 0.01 / 1.03 \pm 0.35 \mu \mathrm{g} / \mathrm{mL}$, respectively. Compounds 5 and 6 selectively inhibited elastase release, with an $\mathrm{IC}_{50}$ values of $1.53 \pm 0.09$ and $3.23 \pm 0.24 \mu \mathrm{g} / \mathrm{mL}$, respectively. Compounds $\mathbf{8}$ and $\mathbf{1 5}$ also exhibited significant anti-inflammatory activity against superoxide anion generation, with $\mathrm{IC}_{50}$ values of $0.93 \pm 0.20$ and $2.66 \pm 0.78 \mu \mathrm{g} / \mathrm{mL}$, respectively.

Table 3. Inhibitory effects of compounds 4-10 and 14-17 from M. fokienensis on superoxide anion generation and elastase release by human neutrophils in response to $\mathrm{MLP} / \mathrm{CB}$.

\begin{tabular}{ccc}
\hline \multirow{2}{*}{ Compounds } & Superoxide anion & Elastase \\
\cline { 2 - 3 } & $\mathrm{IC}_{50}(\mu \mathrm{g} / \mathrm{mL})^{\mathrm{a}}$ or $(\mathrm{Inh} \%)$ & $\mathrm{IC}_{50}(\mu \mathrm{g} / \mathrm{mL})^{\mathrm{a}}$ or $(\mathrm{Inh} \%)$ \\
\hline $\mathbf{4}$ & $125.9 \pm 6.72^{\mathrm{b}} * * *$ & $44.62 \pm 2.82^{\mathrm{c}} * * *$ \\
$\mathbf{5}$ & $19.65 \pm 4.23^{\mathrm{b} * *}$ & $1.53 \pm 0.09$ \\
$\mathbf{6}$ & $(4.35 \pm 6.05)$ & $3.23 \pm 0.24$ \\
$\mathbf{7}$ & $2.10 \pm 0.13$ & $2.93 \pm 0.27$ \\
$\mathbf{8}$ & $0.93 \pm 0.20$ & $4.39 \pm 1.13$ \\
$\mathbf{9}$ & $16.71 \pm 3.39^{\mathrm{b}} * *$ & $5.65 \pm 0.26$ \\
$\mathbf{1 0}$ & $30.27 \pm 5.04^{\mathrm{b}} * * *$ & $5.33 \pm 0.73$ \\
$\mathbf{1 4}$ & $(-2.09 \pm 4.02)$ & $(14.50 \pm 7.26)$ \\
$\mathbf{1 5}$ & $2.66 \pm 0.78$ & $3.23 \pm 0.88$ \\
$\mathbf{1 6}$ & $3.12 \pm 0.60$ & $4.53 \pm 0.39$ \\
$\mathbf{1 7}$ & $0.06 \pm 0.01$ & $1.03 \pm 0.35$ \\
$\mathrm{DPI}^{\mathrm{d}}$ & $0.43 \pm 0.12$ & - \\
$\mathrm{PMSF}^{\mathrm{d}}$ & - & $17.58 \pm 5.79$ \\
\hline
\end{tabular}

Percentage of inhibition (Inh \%) at $10 \mu \mathrm{g} / \mathrm{mL}$ concentration. Results are presented as mean \pm S.E.M. $(n=3-5)$. ** $p<0.01, * * * p<0.001$ compared with the control value; ${ }^{a}$ Concentration necessary for $50 \%$ inhibition $\left(\mathrm{IC}_{50}\right) ;{ }^{\mathrm{b}} \mathbf{4}, \mathbf{5}, \mathbf{9}$, and $\mathbf{1 0}$ induced superoxide anion generation by human neutrophils in absence of $\mathrm{fMLP} / \mathrm{CB} ;{ }^{\mathrm{c}} \mathbf{4}$ induced elastase release by human neutrophils in present of $\mathrm{CB}$; ${ }^{\mathrm{d}}$ Diphenyleneiodonium (DPI, a NADPH oxidase inhibitor) and phenylmethylsulfonyl fluoride (PMSF, a serine protease inhibitior) were used as the positive controls in the generation of superoxide anion and release of elastase, respectively. 


\section{Experimental}

\subsection{General}

The IR spectra were obtained using a Mattson Genesis II spectrometer. ${ }^{1} \mathrm{H}$ and ${ }^{13} \mathrm{C}$-NMR spectra were recorded using Varian VNMR-600, Varian INOVA 500, Varian Unity Plus 400, or Varian Gemini 200 NMR spectrometers. Chemical shifts $(\delta)$ are reported in parts per million, and coupling constants $(J)$ are expressed in Hertz. The LREIMS and LRESIMS were measured using a VG Biotech Quattro 5022 mass spectrometer. The HRESIMS were measured using a Bruker Daltonics APEX $\Pi$ mass spectrometer. Silica gel 60 (Merck, 230-400 mesh) and Sephadex LH-20 were used for column chromatography and TLC analysis was performed on silica gel $\mathrm{GF}_{254}$ pre-coated plates and detection used $50 \% \mathrm{H}_{2} \mathrm{SO}_{4}$ followed by heating on a hot plate. HPLC was performed using a Hitachi L-7100 pump and a D-7000 interface equipped with a Bischoff RI detector using ODS (Hypersil ${ }^{\circledR}, 250 \times 4$ mm; Hypersil $^{\circledR}, 250 \times 10 \mathrm{~mm}$ ) columns.

\subsection{Plant Material}

The dried stems of Microtropis fokienensis were collected from Taichung County, Taiwan, in June 2004, and identified by a botanist, Dr. Hsin-Fu Yen. A voucher specimen (Microtropis-01) was deposited at the Graduate Institute of Natural Products, Kaohsiung Medical University, Kaohsiung, Taiwan.

\subsection{Extraction and Isolation}

The dried stems $(2.85 \mathrm{~kg})$ of $M$. fokienensis were extracted four times with $\mathrm{MeOH}(10 \mathrm{~L})$ overnight at room temperature, followed by removal of the solvent under reduced pressure, to yield a dried $\mathrm{MeOH}$ extract (130 g). The $\mathrm{MeOH}$ extract was dissolved in $\mathrm{H}_{2} \mathrm{O}$ and extracted using EtOAc. Using $n$ hexane and $80 \% \mathrm{MeOH}$, the EtOAc-soluble fraction was divided into $n$-hexane and aqueous $\mathrm{MeOH}$ layers. The aqueous $\mathrm{MeOH}$ layer (38.0 g) was chromatographed on silica gel using mixtures of $n$ hexane-EtOAc of increasing polarity as eluants to afford eighteen fractions. Fr. 10 (2.5 g) was chromatographed on Sephadex LH-20, using $\mathrm{CHCl}_{3}-\mathrm{MeOH}(1: 1)$ to give six subfractions. Fr. 10-2-8 was purified using an ODS HPLC column $\left(250 \times 10 \mathrm{~mm}\right.$, Hypersil $\left.{ }^{\circledR}, \mathrm{MeOH}-\mathrm{H}_{2} \mathrm{O}, 97: 3\right)$ to give $\mathbf{5}$ (14.1 mg, $\mathrm{t}_{\mathrm{R}} 13.4 \mathrm{~min}$, flow rate $\left.2 \mathrm{~mL} / \mathrm{min}\right)$. Fr. 10-3 (132.88 mg) was further separated using an ODS HPLC column $\left(250 \times 10 \mathrm{~mm}\right.$, Hypersil $\left.{ }^{\circledR}, \mathrm{MeOH}-\mathrm{H}_{2} \mathrm{O}, 78: 22\right)$ to afford $1\left(1.3 \mathrm{mg}, \mathrm{t}_{\mathrm{R}} 24.1 \mathrm{~min}\right.$, flow rate $2 \mathrm{~mL} / \mathrm{min}), 2\left(1.9 \mathrm{mg}, \mathrm{t}_{\mathrm{R}} 34.6 \mathrm{~min}\right.$, flow rate $\left.2 \mathrm{~mL} / \mathrm{min}\right), 3\left(1.9 \mathrm{mg}, \mathrm{t}_{\mathrm{R}} 15.4 \mathrm{~min}\right.$, flow rate $2 \mathrm{~mL} / \mathrm{min})$, and $6\left(2.4 \mathrm{mg}, \mathrm{t}_{\mathrm{R}} 51.1 \mathrm{~min}\right.$, flow rate $\left.2 \mathrm{~mL} / \mathrm{min}\right)$. Fr. 12 (5.5 g) was chromatographed on Sephadex LH-20, by elution with $\mathrm{CHCl}_{3}-\mathrm{MeOH}$ (1:1) to give six subfractions. Fr. 12-3 (4.2 g) was subjected to column chromatography over silica gel $\left(\mathrm{CHCl}_{3}-\mathrm{MeOH}\right.$ of increasing polarity) to give twelve subfractions. Fr. 12-3-7 (279 $\mathrm{mg})$ was subjected to passage over an ODS HPLC column $\left(250 \times 10 \mathrm{~mm}\right.$, Hypersil, $\left.\mathrm{MeOH}-\mathrm{H}_{2} \mathrm{O}, 87: 13\right)$ to give 4 (12.1 mg, $\mathrm{t}_{\mathrm{R}} 46.4 \mathrm{~min}$, flow rate $\left.2 \mathrm{~mL} / \mathrm{min}\right)$. Fr. 12-3-8-2 (41.67 mg) was further separated using an ODS HPLC column $\left(250 \times 10 \mathrm{~mm}\right.$, Hypersil ${ }^{\circledR}$, $\left.\mathrm{MeOH}-\mathrm{H}_{2} \mathrm{O}, 90: 10\right)$ to afford $7\left(7.3 \mathrm{mg}, \mathrm{t}_{\mathrm{R}} 15.2 \mathrm{~min}\right.$, flow rate $\left.2 \mathrm{~mL} / \mathrm{min}\right)$. 


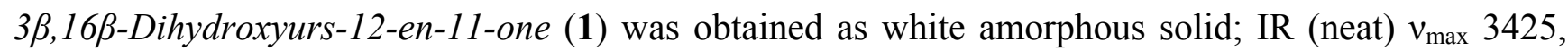
2928, 2869, 1726, 1655, 1456, 1385, 1247, $1208 \mathrm{~cm}^{-1} ;{ }^{1} \mathrm{H}-\mathrm{NMR}\left(\mathrm{C}_{5} \mathrm{D}_{5} \mathrm{~N}, 400 \mathrm{MHz}\right)$ and ${ }^{13} \mathrm{C}-\mathrm{NMR}$ $\left(\mathrm{C}_{5} \mathrm{D}_{5} \mathrm{~N}, 100 \mathrm{MHz}\right)$ see Tables 1 and 2; EIMS $\mathrm{m} / \mathrm{z}[\mathrm{M}]^{+} 456$ (15), 290 (68), 248 (100); HRESIMS $\mathrm{m} / \mathrm{z}$ 479.3501 [M+Na] (calcd. for $\mathrm{C}_{30} \mathrm{H}_{48} \mathrm{O}_{3} \mathrm{Na}, 479.3500$ ).

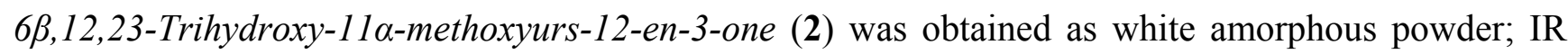
(neat) $v_{\max }$ 3446, 2922, 2858, 1694, 1649, 1456, 1376, $1253 \mathrm{~cm}^{-1} ;{ }^{1} \mathrm{H}-\mathrm{NMR}\left(\mathrm{C}_{5} \mathrm{D}_{5} \mathrm{~N}, 400 \mathrm{MHz}\right)$ and ${ }^{13} \mathrm{C}-\mathrm{NMR}\left(\mathrm{C}_{5} \mathrm{D}_{5} \mathrm{~N}, 100 \mathrm{MHz}\right)$ see Tables 1 and 2; ESIMS $m / z 525[\mathrm{M}+\mathrm{Na}]^{+}$; HRESIMS $m / z 525.3556$ $[\mathrm{M}+\mathrm{Na}]^{+}$(calcd. for $\mathrm{C}_{31} \mathrm{H}_{50} \mathrm{O}_{5} \mathrm{Na}$, 525.3559).

$11 \alpha, 12,16 \beta$-Trihydroxyurs-12-en-3-one (3) was obtained as white amorphous powder; IR (neat) $v_{\max }$ 3418, 2923, 2850, 1694, 1455, 1380, $1252 \mathrm{~cm}^{-1} ;{ }^{1} \mathrm{H}-\mathrm{NMR}\left(\mathrm{C}_{5} \mathrm{D}_{5} \mathrm{~N}, 500 \mathrm{MHz}\right)$ and ${ }^{13} \mathrm{C}-\mathrm{NMR}\left(\mathrm{C}_{5} \mathrm{D}_{5} \mathrm{~N}\right.$, $125 \mathrm{MHz}$ ) see Tables 1 and 2; ESIMS $m / z 495[\mathrm{M}+\mathrm{Na}]^{+}$; HRESIMS $m / z 495.3450[\mathrm{M}+\mathrm{Na}]^{+}$(calcd. for $\mathrm{C}_{30} \mathrm{H}_{48} \mathrm{O}_{4} \mathrm{Na}, 495.3452$ ).

1 $\alpha, 3 \beta$-Dihydroxyolean-12-en-11-one (4) was obtained as white amorphous powder; IR (neat) $v_{\max }$ 3421, 2947, 2856, 1697, 1652, 1458, 1385, $1238 \mathrm{~cm}^{-1} ;{ }^{1} \mathrm{H}-\mathrm{NMR}\left(\mathrm{C}_{5} \mathrm{D}_{5} \mathrm{~N}, 400 \mathrm{MHz}\right)$ and ${ }^{13} \mathrm{C}-\mathrm{NMR}$ $\left(\mathrm{C}_{5} \mathrm{D}_{5} \mathrm{~N}, 100 \mathrm{MHz}\right)$ see Tables 1 and 2; ESIMS $m / z 479$ [M+Na] ${ }^{+}$; HRESIMS $m / z$ 479.3501 [M+Na] (calcd. for $\mathrm{C}_{30} \mathrm{H}_{48} \mathrm{O}_{3} \mathrm{Na}$, 479.3503).

30-Hydroxyolean-12-en-3,11-dione (5) was obtained as white amorphous powder; IR (neat) $v_{\max } 3441$, 2923, 2856, 1697, 1648, 1455, 1384, $1202 \mathrm{~cm}^{-1}$; ${ }^{1} \mathrm{H}-\mathrm{NMR}\left(\mathrm{C}_{5} \mathrm{D}_{5} \mathrm{~N}, 400 \mathrm{MHz}\right)$ and ${ }^{13} \mathrm{C}-\mathrm{NMR}\left(\mathrm{C}_{5} \mathrm{D}_{5} \mathrm{~N}\right.$, $100 \mathrm{MHz}$ ) see Tables 1 and 2; EIMS $m / z[\mathrm{M}]^{+} 454$ (15), 341 (25), 289 (33), 248 (65); HRESIMS $m / z$ 477.3344 [M+Na] (calcd. for $\mathrm{C}_{30} \mathrm{H}_{46} \mathrm{O}_{3} \mathrm{Na}, 477.3341$ ).

33,28-Dihydroxyolean-18-en-1-one (6) was obtained as white amorphous powder; IR (neat) $v_{\max } 3376$, 2951, 2863, 1698, 1632, 1464, 1385, $1248 \mathrm{~cm}^{-1}$; ${ }^{1} \mathrm{H}-\mathrm{NMR}\left(\mathrm{C}_{5} \mathrm{D}_{5} \mathrm{~N}, 400 \mathrm{MHz}\right)$ and ${ }^{13} \mathrm{C}-\mathrm{NMR}\left(\mathrm{C}_{5} \mathrm{D}_{5} \mathrm{~N}\right.$, $100 \mathrm{MHz}$ ) see Tables 1 and 2; ESIMS $m / z 479$ [M+Na] $]^{+}$; HRESIMS $m / z 479.3501[\mathrm{M}+\mathrm{Na}]^{+}$(calcd. for $\left.\mathrm{C}_{30} \mathrm{H}_{48} \mathrm{O}_{3} \mathrm{Na}, 479.3504\right)$.

11 $\alpha, 30$-Dihydroxy-2,3-seco-olean-12-en-2,3-dioic anhydride (7) was obtained as white amorphous powder; IR (neat) $v_{\max } 3426,2923,1712,1454,1394,1373,1263,1235 \mathrm{~cm}^{-1} ;{ }^{1} \mathrm{H}-\mathrm{NMR}\left(\mathrm{C}_{5} \mathrm{D}_{5} \mathrm{~N}, 400\right.$ $\mathrm{MHz})$ and ${ }^{13} \mathrm{C}-\mathrm{NMR}\left(\mathrm{C}_{5} \mathrm{D}_{5} \mathrm{~N}, 100 \mathrm{MHz}\right)$ see Tables 1 and 2; EIMS $m / z[\mathrm{M}]^{+} 486$ (18), 341 (19), 267 (26); HRESIMS $m / z 509.3243[\mathrm{M}+\mathrm{Na}]^{+}$(calcd. for $\mathrm{C}_{30} \mathrm{H}_{46} \mathrm{O}_{5} \mathrm{Na}, 509.3246$ ).

\subsection{The Preparation of Human Neutrophils}

Blood was taken from healthy human donors (20-35 years old) by venipuncture using a protocol approved by the Institutional Review Board at Chang Gung Memorial Hospital. Neutrophils were isolated using a standard method as previously described $[31,32]$.

\subsection{The Measurement of Superoxide Generation}

SOD inhibition was measured by the reduction of ferricytochrome $c$ [31,32]. Neutrophils in $0.5 \mathrm{mg} / \mathrm{mL}$ ferricytochrome $c$ and $1 \mathrm{mM} \mathrm{Ca}^{2+}$ were equilibrated at $37^{\circ} \mathrm{C}$ for $2 \mathrm{~min}$ and then incubated with drugs 
for $5 \mathrm{~min}$. The cells were activated using formyl-methionyl-leucyl-phenylalanine (fMLP, $100 \mathrm{nM}) /$ cytochalasin $\mathrm{B}(\mathrm{CB}, 1 \mu \mathrm{g} / \mathrm{mL})$ for $10 \mathrm{~min}$. The absorbance was continuously monitored at $550 \mathrm{~nm}$ using a double-beam, six-cell positioned spectrophotometer with constant stirring (Hitachi U-3010, Tokyo, Japan). Calculations were based on the differences in absorbance with and without SOD $(100 \mu / \mathrm{mL})$ divided by the extinction coefficient for the reduction of ferricytochrome c $(\varepsilon=21.1 / \mathrm{mM} / 10 \mathrm{~mm})$.

\subsection{The Measurement of Elastase Release}

The degranulation of azurophilic granules was determined by elastase release as described previously [32]. Neutrophils $\left(6 \times 10^{5} / \mathrm{mL}\right)$ were equilibrated in MeO-Suc-Ala-Ala-Pro-Val- $p$ nitroanilide $(100 \mu \mathrm{M})$, an elastase substrate, at $37{ }^{\circ} \mathrm{C}$ for $2 \mathrm{~min}$ and then incubated with drugs for $5 \mathrm{~min}$. The cells were activated using fMLP $(100 \mathrm{nM})$ in the presence of CB $(0.5 \mu \mathrm{g} / \mathrm{mL})$, and changes in the absorbance at $405 \mathrm{~nm}$ were continuously measured to monitor elastase release. The results are expressed as a percentage of the initial rate of elastase release in the fMLP/CB-activated, drug-free control system.

\section{Conclusions}

In this study, a bioassay-guided separation of a $\mathrm{MeOH}$ extract of $M$. fokienensis stems resulted in the isolation of seven new triterpenoids 1-7 and six known compounds 8-13. Their isolation, purification, and structural determination are reported. Compounds 4-10 and 14-17 were tested in an anti-inflammatory assay for effects against superoxide anion generation and elastase release by human neutrophils in response to fMLP/CB. Compounds 7 and $\mathbf{1 7}$ showed significant anti-inflammatory activity against superoxide anion generation and elastase release. Compounds $\mathbf{5}$ and $\mathbf{6}$ exhibited a selective inhibitory effect on elastase release. Compounds 8 and 15 exhibited good anti-inflammatory activity against superoxide anion generation. Interestingly, compound $\mathbf{1 7}$ had a dioic acid function and compound 7 had an anhydride function modification in ring A. Both perform well in the target assays. We propose that the modified dicarbonyl A-ring systems of triterpenoids may play a pivotal role in exhibiting anti-inflammatory biological functions on human neutrophils in response to $\mathrm{ALLP} / \mathrm{CB}$. This is also the first report of the anti-inflammatory effects of a plant from this genus, and these compounds may lead to pharmaceutical advances in the near future.

\section{Supplementary Materials}

Supplementary materials can be accessed at: http://www.mdpi.com/1420-3049/19/4/4608/s1.

\section{Acknowledgments}

We are grateful the financial support from the grants of National Science Council and the grant No. MOHW103-TD-B-111-05 of the Ministry of Health and Welfare, R.O.C. 


\section{Author Contributions}

I-Hsiao Chen participated in the extraction and isolation of M. fokienensis secondary metabolites and in the HPLC purification of the isolated compounds. I-Hsiao Chen and Ying-Chi Du participated in the acquisition of the spectroscopic data and structure identification of the isolated compounds. Tsong-Long Hwang participated in the screening of the isolated compounds anti-inflammatory activity. I-Fen Chen and $\mathrm{Yu}-\mathrm{Hsuan}$ Lan participated in the interpretation of the results and in manuscript writing. Hsin-Fu Yen participated in the identification of M. fokienensis. Yang-Chang Wu and Fang-Rong Chang guided the research and participated in the interpretation of the results.

\section{Conflicts of Interest}

The authors declare no conflict of interest.

\section{References}

1. Flora of Taiwan, 2nd ed.; Huang, T.C., Ed.; Lungwei Printing Co. Ltd Press: Taipei, Taiwan, 1993; Volume 3, pp. 640-658.

2. Chen, J.J.; Chou, T.H.; Duh, C.Y.; Chen, I.S. Cytotoxic dihydroagarofuranoid sesquiterpenes from the stem of Microtropis fokienensis. J. Nat. Prod. 2006, 69, 685-688.

3. Koyama, Y.; Matsunami, K.; Otsuka, H.; Shinzato, T.; Takeda, Y. Microtropiosides A-F: Ent-labdane diterpenoid glucosides from the leaves of Microtropis japonica (Celastraceae). Phytochemistry 2010, 71, 675-681.

4. Chen, I.H.; Chang, F.R.; Wu, C.C.; Chen, S.L.; Hsieh, P.W.; Yen, H.F.; Du, Y.C.; Wu, Y.C. Cytotoxic triterpenoids from the leaves of Microtropis fokienensis. J. Nat. Prod. 2006, 69, 1543-1546.

5. Chen, I.H.; Lu, M.C.; Du, Y.C.; Yen, M.H.; Wu, C.C.; Chen, Y.H.; Hung, C.S.; Chen, S.L.; Chang, F.R.; Wu, Y.C. Cytotoxic triterpenoids from the stems of Microtropis japonica. J. Nat. Prod. 2009, 72, 1231-1236.

6. Chen, I.H.; Du, Y.C.; Lu, M.C.; Lin, A.S.; Hsieh, P.W.; Wu, C.C.; Chen, S.L.; Yen, H.F.; Chang, F.R.; Wu, Y.C. Lupane-type triterpenoids from Microtropis fokienensis and Perrottetia arisanensis and the apoptotic effect of 28-Hydroxy-3-oxo-lup-20(29)-en-30-al. J. Nat. Prod. 2008, 71, 1352-1357.

7. González, A.G.; Andres, L.S.; Ravelo, A.G.; Luis, J.G.; Bazzocchi, I.L.; West, J. Terpenoids from Salvia mellifera. Phytochemistry 1990, 29, 1691-1693.

8. Ikuta, A.; Tomiyasu, H.; Morita, Y.; Yoshimura, K. Ursane- and oleanane-type triterpenes from Ternstroemia gymnanthera Callus Tissues. J. Nat. Prod. 2003, 66, 1051-1054.

9. de Souza e Silva, S.R.; Silva, G.D.F.; Barbosa, L.C.A.; Duarte, L.P.; Vieira Filho, S.A. Lupane pentacyclic triterpenes isolated from stems and branches of Maytenus imbricata (Celastraceae). Helv. Chim. Acta 2005, 88, 1102-1109.

10. Saimaru, H.; Orihara, Y.; Tansakul, P.; Kang, Y.-H.; Shibuya, M.; Ebizuka, Y. Production of triterpene acids by cell suspension cultures of Olea europaea. Chem. Pharm. Bull. 2007, 55, $784-788$. 
11. Cheng, J.J.; Zhang, L.J.; Cheng, H.L.; Chiou, C.T.; Lee, I.J.; Kuo Y.H.; Cytotoxic hexacyclic triterpene acids from Euscaphis japonica. J. Nat. Prod. 2010, 73, 1655-1658.

12. Talapatra, S.K.; Sarkar, A.C.; Talapatra, B. Two pentacyclic triterpenes from Rubia cordifolia. Phytochemistry 1981, 20, 1923-1927.

13. Shibata, S.; Takahashi, K.; Yano, S.; Harada, M.; Saito, H.; Tamura, Y.; Kumagai, A.; Hirabayashi, K.; Yamamoto, M.; Nagara, N. Chemical modification of glycyrrhetinic acid in relation to the biological activities. Chem. Pharm. Bull. 1987, 35, 1910-1918.

14. Taniguchi, S.; Imayoshi, Y.; Kobayashi, E.; Takamatsu, Y.; Shimura, S.; Yoshidda, T. Production of bioactive triterpenes by Eriobotrya japonica calli. Phytochemistry 2002, 59, 315-323.

15. Su, X.; Lawrence, H.; Ganeshapillai, D.; Cruttenden, A.; Purohit, A.; Reed, M.J.; Vickera, N.; Pottera, B.V. L. Novel 18 $\beta$-glycyrrhetinic acid analogues as potent and selective inhibitors of $11 \beta$-hydroxysteroid dehydrogenases. Bioorg. Med. Chem. 2004, 12, 4439-4457.

16. Fingolo, C.E.; de S. Santos, T.; Vianna Filho, M.D.M.; Kaplan, M.A.C. Triterpene esters: Natural products from Dorstenia arifolia (Moraceae). Molecules 2013, 18, 4247-4256.

17. Toriumi, Y.; Kakuda, R.; Kikuchi, M.; Yaoita, Y.; Kikuchi, M. New Triterpenoids from Gentiana lutea. Chem. Pharm. Bull. 2003, 51, 89-91.

18. Morikawa, T.; Oominami, H.; Matsuda, H.; Yoshikawa, M. Four new ursane-type triterpenes, olibanumols K, L, M, and N, from traditional Egyptian medicine olibanum, the Gum-Resin of Boswellia carterii. Chem. Pharm. Bull. 2010, 58, 1541-1544.

19. Shirota, O.; Tamemura, T.; Morita, H.; Takeya, K.; Hideji, I. Triterpenes from Brazilian medicinal plant "Chuchuhuasi” (Maytenus krukovii). J. Nat. Prod. 1996, 59, 1072-1075.

20. Lahlou, H.E.; Hirai, N.; Tsuda, M.; Ohigashi, H. Triterpene phytoalexins from nectarine fruits. Phytochemistry 1999, 52, 623-629.

21. Barnes, R.A.; Pereira, A.L.; Scofield, T.C.V.; Filho, R.B.; Pinto, A.C. A new triterpene from Vellozia compacta. Chem. Pharm. Bull. 1984, 32, 3674-3677.

22. González, A.G.; Fraga, B.M.; González, P.; Hernandez, M.G.; Ravelo, A.G. ${ }^{13}$ C NMR spectra of olean-18-ene derivatives. Phytochemistry 1981, 20, 1919-1921.

23. Osorio, A.A.; Muñóz, A.; Torres-Romero, D.; Bedoya, L.M.; Perestelo, N.R.; Jiménez, I.A.; Alcamí, J.; Bazzocchi, I.L. Olean-18-ene triterpenoids from Celastraceae species inhibit HIV replication targeting NF-kB and Sp1 dependent transcription. Eur. J. Med. Chem. 2012, 52, 295-303.

24. Kuo, Y.H.; Huang, H.C.; Chiou, W.F.; Shi, L.S.; Wu, T.S.; Wu, Y.C. A Novel Anti-NO triterpene, laxifolone-A, and sesquiterpene pyridine alkaloids from Euonymus laxiflorus. J. Nat. Prod. 2003, 66, 554-557.

25. Kagawa, M.; Minami, H.; Nakahara, M.; Takahashi, H.; Takaoka, S.; Fukuyama, Y. Oleanane-type triterpenes from Viburnum awabuki. Phytochemistry 1998, 47, 1101-1105.

26. Wang, K.W. A new fatty acid ester of triterpenoid from Celastrus rosthornianus with anti-tumor activities. Nat. Prod. Res. 2007, 21, 669-674.

27. Okada, Y.; Omae, A.; Okuyama, T. A New Triterpenoid Isolated from Lagerstronemia speciosa (L.) PERS. Chem. Pharm. Bull. 2003, 51, 452-454.

28. Rodrí guez, F.M.; Perestelo, N.R.; Jiménez, I.A.; Bazzocchi, I.L. Friedelanes from Crossopetalum lobatum a new example of a triterpene anhydride. Helv. Chim. Acta 2009, 92, 188-194. 
29. Shernyukov, A.V.; Mainagashev, I.Y.; Korchagina, D.V.; Gatilov, Y.V.; Salakhutdinov, N.F.; Tolstikov, G.A. Reduction of 2,3-seco-28-oxo-19 $\beta, 28$-epoxy-18 $\alpha$-olean-2,3-dicarboxylic acid and its cyclic anhydride. Chem. Nat. Comp. 2011, 47, 237-242.

30. González, A.G.; González, C.M.; Ravelo, A.G. 3-Oxo-28,29-dihydroxyolean-12-ene from Orthosphenia mexicana. J. Nat. Prod. 1986, 49, 148-150.

31. Hwang, T.L.; Su, Y.C.; Chang, H.L.; Leu, Y.L.; Chung, P.J.; Kuo, L.M.; Chang, Y.J. Suppression of superoxide anion and elastase release by $\mathrm{C}_{18}$ unsaturated fatty acids in human neutrophils. J. Lipid Res. 2009, 50, 1395-1408.

32. Hwang, T.L.; Li, G.L.; Lan, Y.H.; Chia, Y.C.; Hsieh, P.W.; Wu, Y.H.; Wu, Y.C. Potent inhibition of superoxide anion production in activated human neutrophils by isopedicin, a bioactive component of the Chinese medicinal herb Fissistigma oldhamii. Free Radic. Biol. Med. 2009, 46, $520-528$.

Sample Availability: Samples of all compounds in the manuscript are available from the authors.

(C) 2014 by the authors; licensee MDPI, Basel, Switzerland. This article is an open access article distributed under the terms and conditions of the Creative Commons Attribution license (http://creativecommons.org/licenses/by/3.0/). 